\title{
SISTEM PENDUKUNG KEPUTUSAN UNTUK PENJADWALAN PENGIRIMAN BARANG PADA PERUSAHAAN JASA ANGKUTAN
}

\author{
Christa Elena Blandina Bire
}

\begin{abstract}
Abstrak :
Pengiriman barang merupakan suatu kegiatan rutin yang dilakukan pada perusahaan jasa angkutan. Banyaknya permintaan pengiriman barang antar kota menyebabkan perusahaan jasa angkutan diharuskan melakukan penjadwalan yang efektif dan efisien. Melakukan penjadwalan pengiriman barang bukanlah pekerjaan yang mudah dikarenakan banyak aspek yang mempengaruhi sehingga menimbulkan masalah dan konflik dalam menyusun jadwal. Melalui tulisan ini, dibangunlah sebuah sistem pendukung keputusan yang membantu perusahaan jasa angkutan dalam melakukan penjadwalan untuk pengiriman barang. Batasan-batasan dalam melakukan penjadwalan digunakan sebagai aturan (rule) dalam sistem pendukung keputusan yang dibangun. Sistem pendukung keputusan ini memberikan alternatif pilihan bagi pengambil keputusan untuk menentukan penjadwalan pengiriman barang berdasarkan waktu pemesanan, ketersediaan sumberdaya, yaitu truk dan supir, serta karakteristik rute perjalanan. Sistem pendukung keputusan ini dibangun menggunakan Microsoft Visual Studio dengan bahasa pemrograman C\#.
\end{abstract}

Kata kunci: Sistem Pendukung Keputusan (SPK), Penjadwalan pengiriman barang.

\section{PENDAHULUAN}

Perkembangan teknologi informasi yang semakin pesat menuntut setiap individu, kelompok maupun suatu perusahaan untuk menerapkannya dalam segala aktifitas. Penggunaan teknologi informasi pada suatu perusahaan sangat dibutuhkan untuk mendukung proses bisnis dari perusahaan tersebut.

Sebuah sistem yang terkomputerisasi dengan baik sangat diperlukan dalam pencapaian efisiensi, terutama pada perusahaan yang mempunyai rutinitas transaksi yang tinggi dan memiliki banyak data yang harus diolah. Banyak data dan informasi yang harus diolah sangat sulit dilakukan dengan cara manual.

Pembuat keputusan kerap dihadapkan pada kerumitan dan lingkup pengambilan keputusan dengan data yang begitu banyak sehingga menjadi suatu keharusan untuk mengandalkan sistem yang mampu memecahkan masalah secara efisien dan efektif yang disebut Sistem Pendukung Keputusan (SPK).

Pengambilan keputusan pada dasarnya merupakan kegiatan manusia yang bertugas untuk mengambil keputusan terhadap suatu permasalahan. Seperti dalam perusahaan, manajer perusahaan harus mengetahui tentang selukbeluk informasi yang diperlukan untuk pengambilan keputusan agar keputusannya tepat dan menguntungkan perusahaan. Dengan pendukung keputusan ini, maka proses pengolahan data menjadi suatu bentuk sistem pendukung keputusan yang terintegrasi dan digunakan secara mudah, cepat, dan akurat.

Pada umumnya, perusahaan jasa angkutan melakukan penjadwalan pengiriman barang secara manual dimana membutuhkan ketekunan 
dan ketelitian yang tinggi. Batasan-batasan dalam melakukan penjadwalan adalah tersedia atau tidaknya sumberdaya yang dibutuhkan pada waktu tertentu dalam proses pengiriman barang. Penjadwalan dengan cara manual tentu saja sangat tidak efektif dan efisien karena membutuhkan waktu yang lama serta memiliki tingkat human error yang tinggi. Hal ini tentunya berpengaruh terhadap kepercayaan pelanggan serta keuntungan dan kerugian perusahaan.

Berdasarkan uraian diatas, maka penulis tertarik untuk membangun sebuah sistem pendukung keputusan pada perusahaan jasa angkutan yang dapat membantu penjadwalan pengiriman barang berdasarkan ketersediaan sumberdaya, yaitu truk dan supir, serta karakteristik rute perjalanan.

Berdasarkan latarbelakang yang ada, maka dirumuskan beberapa masalah sebagai berikut: a. Bagaimana mempermudah dan mempercepat proses penjadwalan pengiriman barang pada perusahaan jasa angkutan?

b.Bagaimana membangun sebuah sistem pendukung keputusan untuk penjadwalan pengiriman barang pada perusahaan jasa angkutan berdasarkan ketersediaan sumberdaya dan karakteristik rute perjalanan?

\section{Sistem Pendukung Keputusan (SPK)}

Konsep Sistem Pendukung Keputusan (SPK) atau Decision Support Systems (DSS) pertama kali diungkapkan pada awal tahun 1970-an oleh Michael S. Scott Morton dengan istilah Management Decision Systems. SPK adalah bagian dari sistem informasi berbasis komputer yang dipakai untuk mendukung pengambilan keputusan dalam suatu organisasi atau perusahaan. Dapat juga dikatakan sebagai sistem komputer yang mengolah data menjadi informasi untuk mengambil keputusan dari masalah semi-terstruktur yang spesifik. Menurut Moore dan Chang, SPK dapat digambarkan sebagai sistem yang berkemampuan mendukung analisis ad hoc data, dan pemodelan keputusan, berorientasi keputusan, orientasi perencanaan masa depan, dan digunakan pada saat-saat yang tidak biasa [8]. Tujuan dari SPK adalah membantu menyelesaikan masalah semi-terstruktur, mendukung manajer dalam mengambil keputusan, serta meningkatkan efektifitas bukan efisiensi pengambilan keputusan. SPK bukanlah suatu tool pengambil keputusan, melainkan sebagai tool pendukung [3]. Komponen-komponen SPK adalah sebagai berikut [7]:

a.Data Management, termasuk database yang mengandung data yang relevan untuk pelbagai situasi dan diatur oleh software yang disebut Database Management Systems (DBMS).

b.Model Management, melibatkan model finansial, statistikal, management science, atau analitis, dan management software yang diperlukan.

c. Communication, dimana user dapat berkomunikasi dan memberikan perintah pada SPK melalui antar muka.

d.Knowledge Management, merupakan subsistem optional yang dapat mendukung subsitem lain atau bertindak sebagai komponen yang berdiri sendiri.

Berikut ini merupakan schematic view SPK:

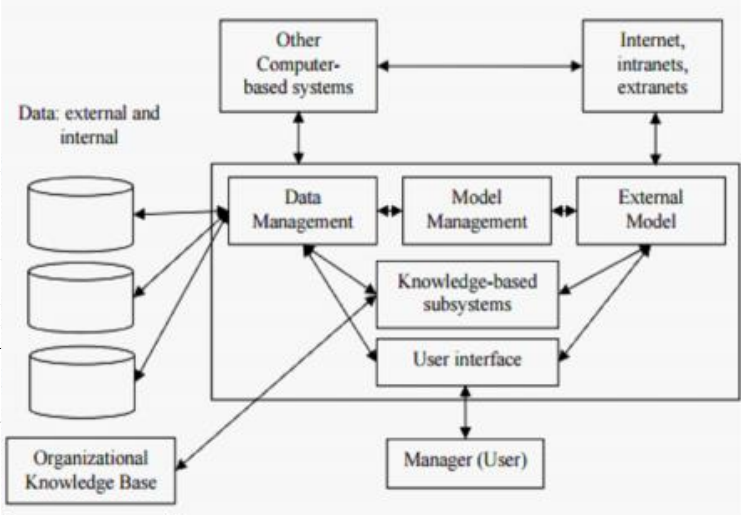

Gambar 1. Schematic view SPK [9]

Beberapa penelitian mengenai sistem pendukung keputusan penjadwalan pernah dilakukan antara lain sistem pendukung keputusan untuk penjadwalan kuliah [12]. Dalam penelitian tersebut, peneliti melakukan penjadwalan kuliah berdasarkan kesediaan waktu dosen 
mengajar. Kriteria-kriteria yang dijadikan acuan penilaian diberi bobot lalu dikalikan dengan nilai dosen berdasarkan masing-masing kriteria. Prioritas penjadwalan mengutamakan dosen dengan point tertinggi. Penelitian mengenai penjadwalan lain adalah sistem penjadwalan trucking dan heavy equipment rental [5], dimana sistem tersebut menggunakan metode AHP untuk pembobotan kriteria sehingga diperoleh skor untuk mengetahui kendaraan mana yang akan digunakan untuk proses pengiriman tertentu. Pada penelitian tersebut, kriteria yang digunakan adalah age, condition, last used, used after service, dan last service, dimana kriteriakriteria ini merupakan kriteria dari kendaraan yang digunakan dalam proses pengiriman.

Pada penelitian ini, penulis merancang dan membangun sebuah sistem pendukung keputusan yang membantu proses pengambilan keputusan untuk penjadwalan pengiriman barang pada perusahaan jasa angkutan. Pada sistem pendukung keputusan ini, penulis memperhatikan berbagai faktor yang diperlukan sebagai batasan. Batasan-batasan ini dipakai sebagai kriteria atau aturan untuk mendukung pengambilan keputusan. Penelitian ini tidak menggunakan pembobotan pada kriteria karena yang menjadi permasalahan adalah tersedia atau tidaknya sumberdaya, serta karakteristik rute antar kota yang disesuaikan dengan truk yang mengirimkan barang. Prioritas untuk penjadwalan adalah kepada siapa yang melakukan pemesanan (order) terlebih dahulu, namun juga memperhatikan tersedia atau tidaknya sumberdaya yang memadai pada waktu tertentu. Selain itu, penyampaian informasi kepada pelanggan berupa estimasi lama pengiriman setelah order lebih akurat.

\section{Penjadwalan Pengiriman Barang}

Penjadwalan merupakan suatu fungsi pengambil keputusan, yaitu sebuah proses untuk membuat suatu jadwal. Batasan dalam penjadwalan pengriman barang adalah sebagai berikut:
1.Sebuah truk hanya dapat digunakan untuk satu pengiriman pada waktu tertentu.

2.Seorang supir hanya dapat menyetir satu truk pada waktu tertentu.

3. Sebuah tipe truk hanya dapat digunakan untuk karakteristik rute tertentu.

4.Barang tidak dapat dialokasikan pada suatu truk yang menyebabkan truk melebihi kapasitas maksimum (overload).

5.Pada waktu tertentu, truk dan supir yang sedang dalam proses pengiriman tidak dapat diberdayakan.

\section{METODOLOGI PENELITIAN}

Tahapan proses metodologi penelitian yang dilakukan dalam penelitian ini terdapat pada gambar berikut:

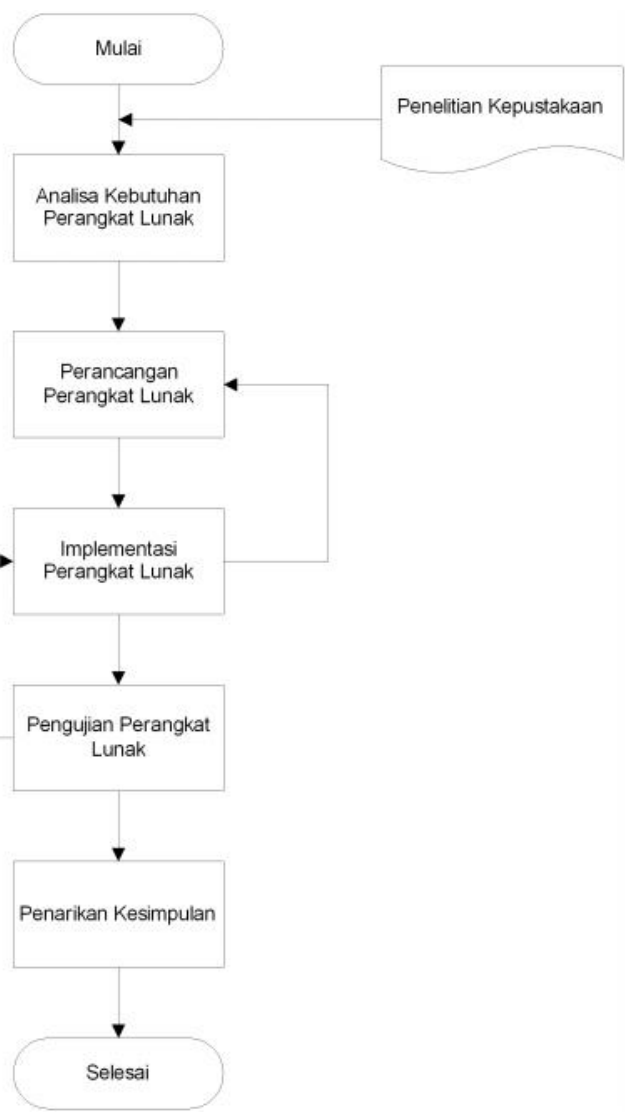

Gambar 2. Flowchart metodologi penelitian 


\section{Diagram Use Case}

Kebutuhan fungsional sistem dapat dilihat pada Diagram Use Case berikut:

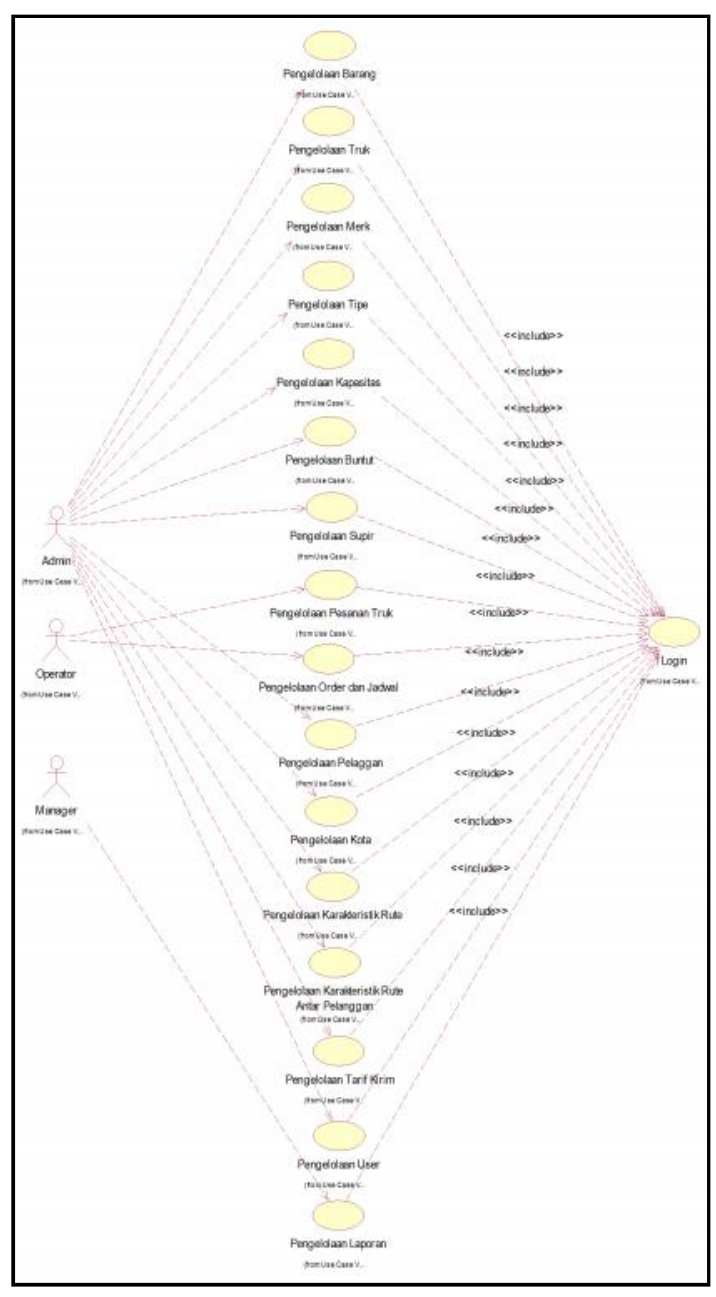

Gambar 3. Diagram Use Case

Terdapat tiga pengguna sistem yaitu Admin, Operator, dan Manajer. Admin memiliki hak akses untuk menambah, mengedit, serta menghapus data barang, data pelanggan, data truk, data supir, karakteristik rute pengiriman, tarif pengiriman dan data pengguna sistem. Manajer memiliki hak akses untuk menampilkan empat jenis laporan yaitu laporan pemasukan, laporan laju pemesanan, laporan pemakaian truk, dan laporan jadwal pengiriman barang. Operator memiliki hak akses untuk menambah, mengedit, dan menghapus data pemesanan dan jadwal pengiriman barang.

\section{Antar Muka Perangkat Lunak}

Berikut ini merupakan beberapa tampilan penting dari perangkat lunak yang dibangun:

1. Login

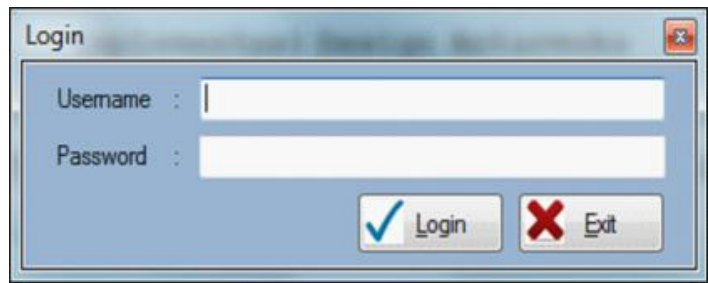

Gambar 4. Antarmuka Login

Antarmuka ini digunakan untuk melakukan proses login ke dalam sistem. Untuk mendapat akses masuk ke dalam sistem, pengguna (user) harus memasukkan username dan password dengan benar pada textbox yang telah disediakan. Pada saat button login ditekan, sistem akan mengecek username dan password yang diinputkan dengan data username dan password yang telah tersimpan di database. Jika data username dan password benar atau cocok maka pengguna akan masuk ke dalam sistem, sebaliknya jika username dan password salah atau tidak cocok maka akan diberikan pesan peringatan. Setelah login berhasil maka pengguna yang bersangkutan akan masuk ke dalam menu utama.

\section{Menu Utama}

\section{Gambar 5. Antarmuka Menu Utama}

Antar muka ini digunakan untuk menampilkan menu yang ada pada sistem. Pada antarmuka ini, terdapat 6 buah menu item, yaitu File, Pengelolaan Umum, Pengelolaan Truk, dan Pengelolaan Jadwal, Sistem, dan Pengelolaan 


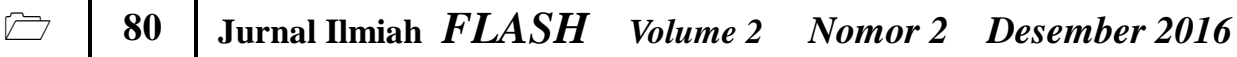

Laporan yang harus dipilih oleh pengguna untuk membuka atau memilih pilihan menu berikutnya. Pada menu item File terdapat pilihan menu Ganti Password, Logout, dan Exit. Pada menu item Pengelolaan Umum terdapat 6 submenu yaitu Barang, Kota, Rute, Kapasitas, Tarif, dan Pelanggan. Pada menu Pengelolaan Truk terdapat 2 submenu, yaitu Truk dan Supir. Pada menu Pengelolaan Order dan Jadwal terdapat 1 submenu yaitu Order. Pada menu Sistem terdapat 1 submenu yaitu User. Pada menu Pengelolaan Laporan terdapat 1 submenu yaitu Generate laporan. Jika pengguna login sebagai administrator, maka menu yang akan tampil adalah menu File, Pengelolaan Umum, Pengelolaan Truk, dan Sistem. Jika pengguna login sebagai operator, maka menu yang akan tampil adalah menu File dan Pengelolaan Order dan Jadwal. Jika pengguna login sebagai manajer, maka menu yang tampil adalah menu File dan menu Pengelolaan Laporan.

\section{Pengelolaan Order dan Jadwal}

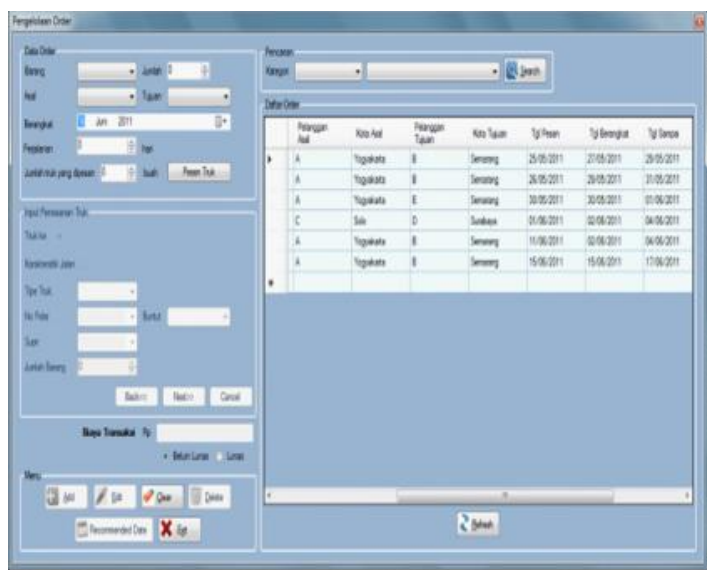

Gambar 6. Antarmuka Pengelolaan Order dan Jadwal

Antarmuka ini digunakan untuk melakukan pengelolaan order dan jadwal. Pada antarmuka ini, pengguna dapat menginputkan data pemesanan (order) pada textbox dan combobox yang tersedia. Button Pesan Truk digunakan untuk mengaktifkan groupbox input pesanan truk sehingga data pesanan truk dapat diinputkan. Button Insert digunakan untuk menginputkan data order dan jadwal serta pesanan truk ke dalam sistem. Jika data pada gridview di double-click maka akan mengaktifkan button Update dan button Delete serta mengubah text "Pesan Truk" pada button Pesan Truk menjadi "Edit Pesanan Truk". Button Update digunakan untuk mengubah data order dan jadwal yang telah dipilih dan diedit. Button Delete digunakan untuk menghapus order dan jadwal yang dipilih. Button Clear digunakan untuk mengosongkan data pada textbox dan combobox. Button Search digunakan untuk mencari data order dan jadwal yang diinginkan. Button Refresh digunakan untuk merefresh daftar order dan jadwal pada gridview. Button Exit digunakan untuk keluar dari antarmuka ini. Data order dan jadwal yang diinputkan adalah berupa data barang, total barang, asal, tujuan, dan jadwal pengiriman barang. Dalam menentukan jadwal pengiriman, harus memenuhi kriteria ketersediaan truk dan supir. Ketika user menginputkan pelanggan asal dan pelanggan tujuan, sistem akan mengecek karakteristik rute antar pelanggan. Kemudian sistem akan memberikan pilihan tipe truk berdasarkan karakteristik rute serta pilihan truk dan supir yang tersedia, dalam hal ini truk dan supir dalam status available dan tidak dalam proses pengiriman. Ketika user menginputkan tanggal pengiriman dimana pada tanggal tersebut tidak ada truk atau supir yang tersedia, maka user dapat memilih recomended date oleh sistem. Dalam pemesanan truk, sistem juga membatasi jumlah barang berdasarkan kapasitas maksimum dari truk yang dipilih.

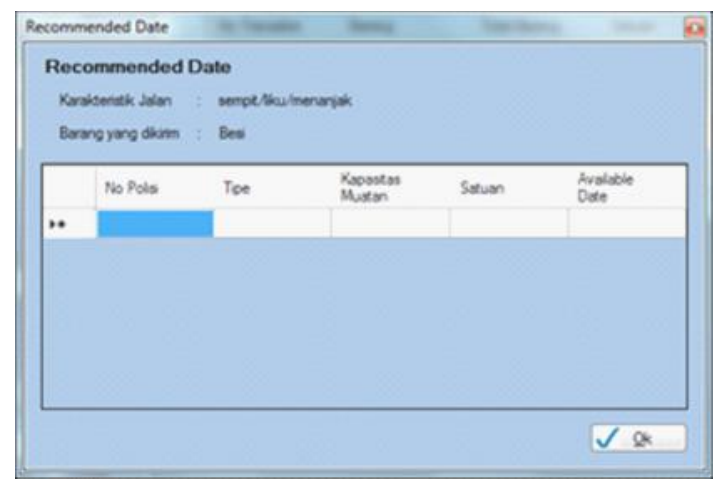

Gambar 7. Recomended Date 
Recomended date merupakan daftar truk dan tanggal yang bisa dipakai untuk pengiriman (available date). Recomended date ditampilkan berdasarkan karakteristik rute dan tanggal pengiriman dimana truk-truk tersebut tidak dalam proses pengiriman barang.

4. Pengelolaan Laporan

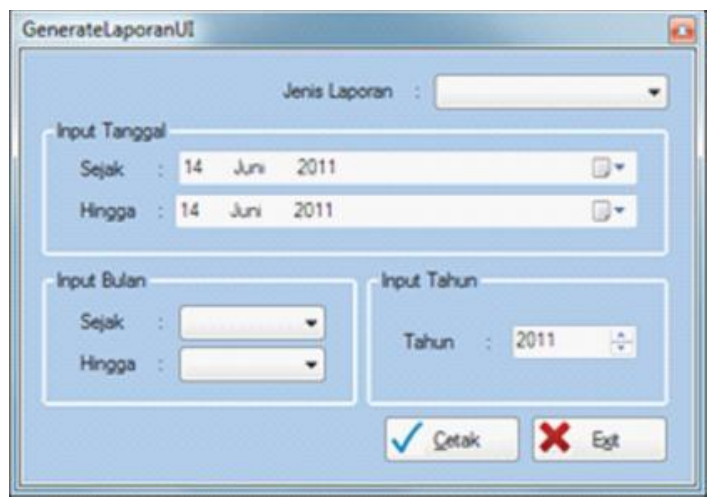

Gambar 8. Pengelolaan Laporan

Antarmuka ini digunakan untuk mencetak laporan pemasukan, laporan laju pemesanan, dan laporan pemakaian truk. Pada antarmuka ini, terdapat combobox jenis laporan dimana user harus memilih jenis laporan yang ingin dicetak. Jika pengguna memilih laporan pemasukan, maka pengguna harus memasukkan tanggal sejak dan tanggal hingga laporan pemasukan yang ingin dicetak. Setelah tanggal dipilih kemudian pengguna menekan button Cetak, maka akan tertampil report pemasukan pada bagian crystalreport.

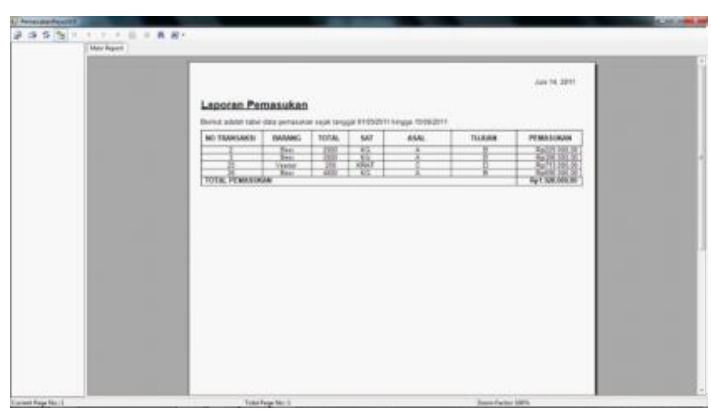

Gambar 9. Laporan Pemasukan

Jika pengguna memilih laporan laju pemesanan, maka pengguna harus memasukkan bulan sejak dan bulan hingga laporan pemesanan yang ingin dicetak. Setelah bulan dipilih kemudian pengguna menekan button Cetak, maka akan tertampil report laju pemesanan pada bagian crystalreport.

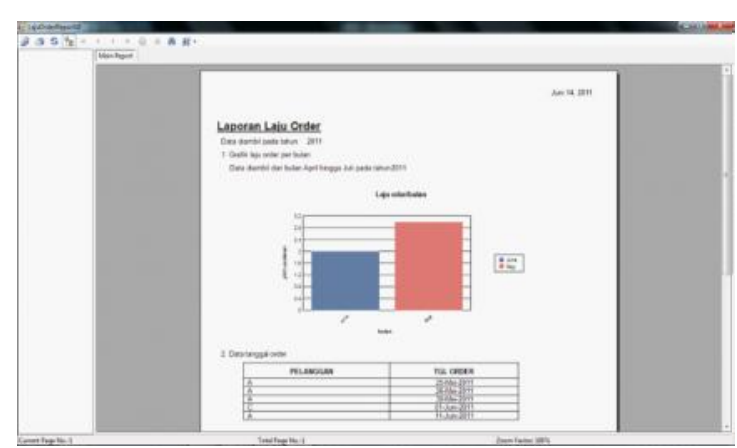

Gambar 10. Laporan Laju Pemesanan

Jika pengguna memilih laporan pemakaian truk, maka pengguna harus memasukkan bulan laporan pemakain truk yang ingin dicetak. Setelah bulan dipilih kemudian pengguna menekan button Cetak, maka akan tertampil report pemakaian truk pada bagian crystal report.

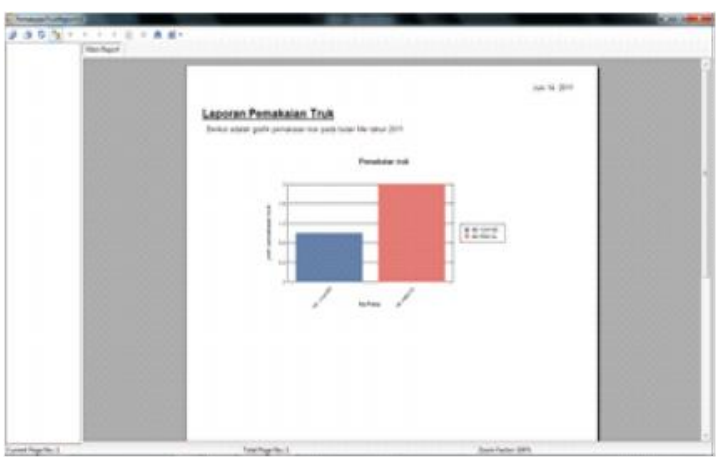

Gambar 11. Laporan Pemakaian Truk

Jika pengguna memilih laporan jadwal pengiriman, maka pengguna harus memasukkan tanggal sejak dan tanggal hingga laporan pemasukan yang ingin dicetak. Setelah tanggal dipilih kemudian pengguna menekan button Cetak, maka akan tertampil report pemasukan pada bagian crystalreport. 


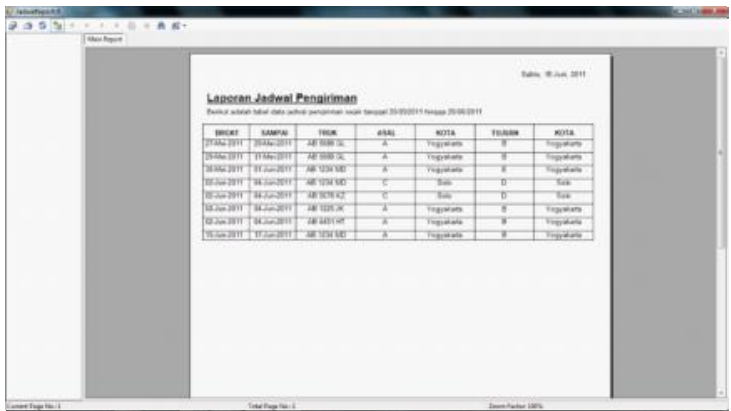

Gambar 12. Laporan Jadwal Pengiriman

\section{PEMBAHASAN}

\section{Pengujian Perangkat Lunak}

Pengujian perangkat lunak dilakukan dengan menguji setiap form pada sistem pendukung keputusan untuk melihat hasil yang diberikan. Prosedur pengujian yaitu menginputkan data-data yang diperlukan sesuai tampilan form dimana data yang diinputkan berupa data yang benar maupun data yang salah. Keluaran yang diharapkan dibandingkan dengan hasil yang didapat dan disesuaikan dengan kriteria evaluasi hasil. Kesimpulan yang didapat adalah setiap form memberikan hasil yang sesuai dengan harapan. Berikut adalah contoh hasil pengujian terhadap form pengelolaan order dan jadwal:

a)Pengujian input data pemesanan:

Prosedur pengujian:

1) Masukkan jenis barang, total barang, pelanggan asal, pelanggan tujuan, tanggal berangkat, tipe truk, nomor polisi truk, nama supir, dan status lunas

2) Tekan tombol Add

Masukan:

3) Jenis barang ("Besi”) pada combobox nama barang

4) Total barang ("2000”) pada textbox total barang

5) Pelanggan asal (“A”) pada combobox pelanggan asal

6) Pelanggan tujuan ("B") pada combobox pelanggan tujuan

7) Tanggal berangkat ("20/05/2016") pada date time picker berangkat
8) Tipe truk ("Tronton") pada combobox tipe

9) Nomor polisi ("AB 1225 JK”) pada combobox nomor polisi

10) Nama supir (“Andy”) pada combobox nama supir

11) Tekan tombol Add

Keluaran yang diharapkan:

12) Muncul message "Data telah diinputkan". Jika dipilih "Ok" maka akan kembali ke form Pengelolaan Order dan Jadwal.

13) Database terupdate; data grid view menam-pilkan jadwal pengiriman barang beserta keterangan pemesanan dan pengiriman

Hasil yang didapat:

14) Muncul message "Data telah diinputkan". Jika dipilih "Ok" maka akan kembali ke form Pengelolaan Order dan Jadwal

15) Database terupdate; data grid view menampilkan jadwal pengiriman barang beserta keterangan pemesanan dan pengiriman

b)Pengujian input dua pemesanan pada tanggal yang sama jika salah satu pemesanan mempunyai kasus dimana truk sedang dalam status Not Available (NA).

Prosedur pengujian:

1) Masukkan jenis barang, total barang, pelanggan asal, pelanggan tujuan, tanggal berangkat, tipe truk, nomor polisi truk, nama supir, dan status lunas

2) Tekan tombol Add

Masukan:

c)Pemesanan pertama

1) Jenis barang ("Besi") pada combobox nama barang

2) Total barang ("1000") pada textbox total barang

3) Pelanggan asal ("A") pada combobox pelanggan asal

4) Pelanggan tujuan ("B") pada combobox pelanggan tujuan

5) Tanggal berangkat (“20/08/2016”) pada date time picker berangkat

6) Tipe truk ("Tronton") pada combobox tipe 
7) Nomor polisi (“AB 1225JK”) pada combobox nomor polisi

8) Nama supir ("Andy") pada combobox nama supir

9) Tekan tombol Add

Keterangan: truk yang diperkenankan untuk karakteristik rute dari A ke B sedang NA

d)Pemesanan kedua

1) Jenis barang ("Besi") pada combobox nama barang

2) Total barang ("2500”) pada textbox total barang

3) Pelanggan asal ("D") pada combobox pelanggan asal

4) Pelanggan tujuan (“E”) pada combobox pelanggan tujuan

5) Tanggal berangkat ("20/08/2016”) pada date time picker berangkat

6) Tipe truk ("Trailer") pada combobox tipe

7) Nomor polisi ("AB 1234 DD”) pada combobox nomor polisi

8) Nama supir ("Budy") pada combobox nama supir

9) Tekan tombol Add

Keterangan: truk yang diperkenankan untuk karakteristik rute dari D ke E tersedia

Keluaran yang diharapkan:

e)Pemesanan pertama

1) SPK menampilkan recomended date, kemudian pengguna akan memilih salah satu dari daftar tanggal yang direkomendasikan

2) Muncul message "Data telah diinputkan". Jika dipilih "Ok" maka akan kembali ke form Pengelolaan Order dan Jadwal

3) Database terupdate; data grid view menampilkan jadwal pengiriman barang beserta keterangan pemesanan dan pengiriman

f)Pemesanan kedua

1) Muncul message "Data telah diinputkan". Jika dipilih "Ok" maka akan kembali ke form Pengelolaan Order dan Jadwal
2) Database terupdate; data grid view menampilkan jadwal pengiriman barang beserta keterangan pemesanan dan pengiriman

3) Jadwal: pemesanan kedua mempunyai tanggal pengiriman yang lebih dahulu dari pada pemesanan pertama

Hasil yang didapat:

g)Pemesanan pertama

1) SPK menampilkan recomended date, kemudian pengguna memilih salah satu dari daftar tanggal yang direkomendasikan

2) Muncul message "Data telah diinputkan". Jika dipilih "Ok" maka akan kembali ke form Pengelolaan Order dan Jadwal

3) Database terupdate; data grid view menampilkan jadwal pengiriman barang beserta keterangan pemesanan dan pengiriman

h)Pemesanan kedua

1) Muncul message "Data telah diinputkan". Jika dipilih "Ok" maka akan kembali ke form Pengelolaan Order dan Jadwal

2) Database terupdate; data grid view menampilkan jadwal pengiriman barang beserta keterangan pemesanan dan pengiriman

3) Jadwal: pemesanan kedua mempunyai tanggal pengiriman yang lebih dahulu dari pada pemesanan pertama

i) Pengujian input pemesanan (seluruh supir sedang dalam status NA)

Prosedur pengujian:

1) Masukkan jenis barang, total barang, pelanggan asal, pelanggan tujuan, tanggal berangkat, tipe truk, nomor polisi truk, nama supir, dan status lunas

2) Tekan tombol Add

Masukan:

3) Jenis barang ("Besi") pada combobox nama barang

4) Total barang ("2000”) pada textbox total barang 
5) Pelanggan asal (“A”) pada combobox pelanggan asal

6) Pelanggan tujuan ("B") pada combobox pelanggan tujuan

7) Tanggal berangkat (“25/11/2016”) pada date time picker berangkat

8) Tipe truk ("Tronton") pada combobox tipe

9) Nomor polisi (“AB 1225 JK”) pada combobox nomor polisi

10) Nama supir (“Andy”) pada combobox nama supir

11) Tekan tombol Add

Keluaran yang diharapkan:

12) SPK menampilkan recomended date, kemudian pengguna akan memilih salah satu dari daftar tanggal yang direkomendasikan

13) Muncul message "Data telah diinputkan". Jika dipilih "Ok" maka akan kembali ke form Pengelolaan Order dan Jadwal

14) Database terupdate; data grid view menampilkan jadwal pengiriman barang beserta keterangan pemesanan dan pengiriman

Hasil yang didapat:

1) SPK menampilkan recomended date, kemudian pengguna memilih salah satu dari daftar tanggal yang direkomendasikan

2) Muncul message "Data telah diinputkan". Jika dipilih "Ok" maka akan kembali ke form Pengelolaan Order dan Jadwal

3) Database terupdate; data grid view menampilkan jadwal pengiriman barang beserta keterangan pemesanan dan pengiriman

j) Pengujian input pemesanan (salah satu data dikosongkan)

Prosedur Pengujian:

1) Masukkan jenis barang, pelanggan asal, pelanggan tujuan, tanggal berangkat, tipe truk, nomor polisi truk, nama supir, dan status lunas

2) Total barang dikosongkan

3) Tekan tombol Add
Masukan:

1) Jenis barang ("Veener") pada combobox nama barang

2) Pelanggan asal ("C") pada combobox pelanggan asal

3) Pelanggan tujuan (“E”) pada combobox pelanggan tujuan

4) Tanggal berangkat ("24/05/2016”) pada date time picker berangkat

5) Tipe truk ("Trailer") pada combobox tipe

6) Nomor polisi pada ("AB 5688 GL”) combobox nomor polisi

7) Nama supir ("Budy") pada combobox nama supir

8) Tekan tombol Add

Keluaran yang diharapkan:

Muncul message "Data tidak lengkap!". Jika dipilih "Ok" maka akan kembali ke form Pengelolaan Order dan Jadwal.

Hasil yang didapat:

Muncul message "Data tidak lengkap!". Jika dipilih "Ok" maka akan kembali ke form Pengelolaan Order dan Jadwal

k) Pengujian edit pemesanan

Prosedur pengujian:

1) Pilih data pemesanan yang hendak diedit pada gridview

2) Edit data pemesanan yang diperlukan

3) Tekan tombol Edit

Masukan:

4) Pilih data pemesanan (data pemesanan mempunyai jenis barang "Besi") pada gridview

5) Ganti jenis barang truk ("Veener")

6) Tekan tombol Edit

Keluaran yang diharapkan:

1) Muncul message "Data berhasil diupdate". Jika dipilih "Ok" maka akan kembali ke form Pengelolaan Order dan Jadwal

2) Database terupdate; data grid view menampilkan data order dan jadwal terbaru 
Hasil yang didapat:

1) Muncul message "Data berhasil diupdate". Jika dipilih "Ok" maka akan kembali ke form Pengelolaan Order dan Jadwal

2) Database terupdate; data grid view menampilkan data order dan jadwal terbaru

1) Pengujian hapus pemesanan

Prosedur pengujian:

1) Pilih data pemesanan yang hendak dihapus pada gridview

2) Tekan tombol Delete

Masukan:

3) Pilih data pemesanan (data pemesanan mempunyai jenis barang "Besi”) pada gridview

4) Tekan tombol Delete

Keluaran yang diharapkan:

Muncul message "Data berhasil dihapus". Jika dipilih "Ok" maka akan kembali ke form Pengelolaan Order dan Jadwal

Hasil yang didapat:

Muncul message "Data berhasil dihapus". Jika dipilih "Ok" maka akan kembali ke form Pengelolaan Order dan Jadwal

m)Pengujian pencarian (search) pemesanan

Prosedur pengujian:

1) Pilih kategori pencarian

2) Masukkan kata kunci pencarian pemesanan

3) Tekan tombol Search

Masukan:

1) Kategori ("Tgl Pesan") pada combobox kategori pencarian

2) Kata kunci pencarian pemesanan ("20/05/ 2016") pada textbox pencarian

3) Tekan tombol Search

Keluaran yang diharapkan:

Gridview akan menampilkan data order dan jadwal dengan tanggal pesan "20/05/2016"

Hasil yang didapat:

Gridview menampilkan data order dan jadwal dengan tanggal pesan "20/05/2016"

\section{KESIMPULAN}

Berdasarkan pembahasan di atas, maka dapat ditarik beberapa kesimpulan yaitu:

a) Sebuah sistem pendukung keputusan bertujuan untuk membantu proses pengambilan keputusan, bukanlah untuk menggantikan pengambil keputusan

b) Pembuatan sistem pendukung keputusan untuk penjadwalan pengiriman barang pada perusahaan jasa angkutan dibangun menggunakan Microsoft Visual Studio, dengan bahasa pemrograman $\mathrm{C \#}$

c) Pengguna berinteraksi dengan sistem melalui Graphical UserInterface(GUI) yang menampilkan data, yang disesuaikan dengan hak akses pengguna

d) Berdasarkan hasil pengujian, sistem pendukung keputusan mampu melakukan penjadwalan berdasarkan kriteria yang telah ditetapkan sebagai batasan dalam pemesanan maupun penjadwalan sehingga proses pemesanan dan penjadwalan lebih mudah, cepat, dan akurat

e) Batasan-batasan dalam melakukan penjadwalan adalah tersedia atau tidaknya sumberdaya yaitu truk dan supir, karakteristik rute, serta waktu pemesanan, yang digunakan sebagai kriteria pertimbangan dalam pemesanan dan penjadwalan.

\section{DAFTAR PUSTAKA}

Blaha, Michael \& Rumbaugh, James 2005, Object Oriented Modeling and Design With $U M L$ (2nd ed), New Jersey: Pearron Education Inc.

Clark, Dan, 2011, Beginning C\# ObjectOriented Programming, Apress, Berkeley, CA.

Permatasari, Hanis Setiawati, Awang Harsa Kridalaksana, dan Addy Suyatno, 2015, Sistem Pendukung Keputusan Pemilihan Program Studi Di Universitas Mulawarman Menggunakan Metode Tsukamoto (Studi kasus : Fakultas MIPA), Jurnal Informatika Mulawarman, Vol. 10 No. 1. 


\section{\begin{tabular}{l|l|llll}
$\square$ & 86 & Jurnal Ilmiah FLASH & Volume 2 & Nomor 2 & Desember 2016
\end{tabular}}

Rosenberg, Doug and Matt Stephens, 2007, Use Case Driven Object Modeling with UML: Theory and Practice, Apress, Berkeley, CA.

Setiawan, Alexander, Herry Christian Palit, dan Livia Kirana Utomo, 2009, Imple-mentasi Sistem Penjadwalan Trucking Dan Heavy Equipment Rental Dengan Menggunakan Analytical Hierarchy Process (AHP), Seminar Nasional Informatika, ISSN 19792328.

Sitepu, Kadar Eratosthenes, 2010, Sistem Pendukung Keputusan Penjadwalan Mata Kuliah dengan Model Pemrograman Heuristic Menggunakan Algoritma A*, Skripsi S1, Universitas Sumatera Utara, Medan.

Subakti, Irfan, 2002, Sistem Pendukung Keputusan (Decision Support System), Fakultas Teknologi Informasi, Institut Teknologi Sepuluh November, Surabaya.
Tariq, Ahmad dan Khan Rafi, 2012, Intelligent Decision Support Systems- A Framework, Information and Knowledge Management, ISSN 2224-896X, Vol 2, No.6.

Tripathi, K P, 2011, Decision Support System Is A Tool For Making Better Decisions In The Organization, Indian Journal of Computer Science and Engineering, Vol. 2 No. 1, ISSN : 0976-5166.

Turban, Efraim, Decision Support and Expert Systems: Management Systems, Fourth Edition, Prentice-Hall, Inc., United Staets of America, 1995.

Turban, E., Aronson, J. E., and Liang, T. Decision Support Systems and Intelligent Systems ( $7^{\text {th }}$ edition), Prentice Hall Publication, pp. 223 and pp. 109, 707, 2005.

Yuhilda, 2007, Aplikasi Sistem Pendukung Keputusan Penjadwalan Kuliah Berdasarkan Kesediaan Waktu Dosen Mengajar, Jurnal Dasi, Vol 8, No 4. 